\title{
Comparison of The Function of Neutrophil Cells Oxidative Burst Among Various Group Ages
}

\author{
Dwi Setyawan', Gatot Soegiarto ${ }^{2 *}$, Novira Widajanti ${ }^{3}$ \\ ${ }^{1}$ Department of Internal Medicine, Faculty of Medicine, Universitas Airlangga - Dr. Soetomo General Hospital Surabaya, \\ Indonesia. \\ ${ }^{2}$ Division of Allergy and Immunology, Department of Internal Medicine, Faculty of Medicine, Universitas Airlangga - Dr. \\ Soetomo General Hospital Surabaya, Indonesia. \\ ${ }^{3}$ Division of Geriatric, Department of Internal Medicine, Faculty of Medicine, Universitas Airlangga - Dr. Soetomo General \\ Hospital Surabaya, Indonesia.
}

\begin{abstract}
A B S T R A C T
Background: In old ages there is a change in the immune system along with the aging process called the term immunosenescence. Neutrophil cells play an important role in natural immunity because they are the first immune cells to be deployed in the body's defenses.

Objective: To prove that there is a difference in the function of neutrophil cell oxidative burst in older age group compared with the younger age group as well as the tendency of decreased oxidative burst function of neutrophil cells with increasing age.

Methods: This is a cross-sectional observational analytic study involving 48 healthy subjects. The subjects were divided into 3 age groups: young age (18-40 years old), middle age (41-59 years old), and old age $\geq 60$ years old). Each of them were examined for the function of neutrophil cells oxidative burst. The data were then analyzed using one-way ANOVA test. The result was considered significant if $\mathrm{p}<0.05$.

Results: The obtained mean age $59.26 \pm 8.03$ years old. The mean age for young age group was $28.75 \pm 6.66$ years old. The mean of middle age group was $50.19 \pm 5.46$ years old. The mean age of old group was $66.38 \pm 3.83$ years old. The mean of netrofil oxidative burst cell function was $96.83 \pm 2.7 \%$ with mean of young age being $98.57 \pm 0.98 \%$, middle age $97.71 \pm 1.64 \%$, and old age $94.20 \pm 3.56 \%$. One way ANOVA comparison analysis showed a significant difference with $\mathrm{p}=0.000$ (significant when $\mathrm{p}<0.05$ ). The result of Rank Spearman test showed significant result with $\mathrm{r}=-0.590(\mathrm{p}=0.000)$.

Conclusion : There are differences in the function of neutrophil cells oxidative burst between young and old age groups. There is a negative trend between the age group and the function of neutrophil cell oxidative burst. The increase of age causes decrease in the function of neutrophil cells oxidative burst.
\end{abstract}

Keywords: : Immunosenescence, Neutrophil Cells Oxidative Burst, Young Age, Middle Age, Old Age.

Correspondence: Gatot Soegiarto

E-mail: gatotsby@yahoo.com

Article history: • Received 03 January $2020 \bullet$ Received in revised form 16 January $2020 \bullet$ Accepted 28 January 2020

\section{INTRODUCTION}

The process of aging is a physiological change that develops with increasing age resulting in progressive decline of all organs of the body (Hadi M, 2011). In older age there is a change in the immune system along with the aging process called as immunosenescence (Balcombe and Sinclair, 2001). Decreased immune function is not only found in the adaptive immune system (decreased T lymphocyte function due to decreased proliferation and cytokine secretion, decreased antibody production by B lymphocyte) but also in immuninnate system (decreased functional activity of neutrophil cells, macrophages, dendritic cells and Natural Killer cells). Neutrophil plays an important role in natural immunity because it is the first immune cells deployed in the body's defense against bacterial, viral or fungal infections (Lord et al., 2001, Plackett et al., 2004).

According to demographic data of world population, by 2050 it is estimated that about $50 \%$ of the elderly population will reach the age of 80 years and above. The number of elderly people in Indonesia is estimated to increase by 2020 to 20 million or $11.4 \%$ of the population (WHO Regional Office for South East Asia, 2004). As the age increases there is an increase in morbidity and mortality among the elderly. The main factor that can explain it is immunosenescence. At old age there is a decrease in the ability of the immune system, both to respond to infection and to form long-term immune memory (Weinberger et al., 2008). The result of the National Health Survey in Indonesia in 1995 showed morbidity in elderly $>60$ years old at $9.2 \%$, in 2005 the morbidity increased to $29.98 \%$, and in 2007 increased again to $31.11 \%$ dominated by infectious diseases (Hadi M, 2011).

All immune cells are affected by age and contribute to the increased susceptibility of elderly to infections and mortality. The process of infection in the elderly often comes with symptoms and signs that are not typical. The guidance of focal infection is often not seen or obscured by the underlying chronic conditions. This will create problems in diagnosis and treatment (Ginaldi et al., 2001). Neutrophil cells are important immune cells in the natural 
immune system and become the first immune cells to come into place of infection. For examination of netrophil function activity in removing reactive oxygene species is called oxidative burst. In general, functional changes obtained in the elderly are associated with signal delivery disorder, but the mechanism is unknown (Wenisch et al., 2000, Wessels et al., 2010). Many factors are suspected to affect, including hormonal changes (Butcher et al., 2005). The adrenal gland cortex produces the hormone dehydroepiandrosterone/dehydroepiandrosterone sulphate (DHEA / DHEAS). In the elderly hormone production is decreased to enly $10-20 \%$ of the maximum, cortisol hormone production does not decrease with age (Orentreich et al., 1992). High serum cortisol levels lead to suppression of superoxide production by neutrophil cells (Bekesi et al., 2000, Mitchell et al., 2002). The role of DHEA/DHEAS hormone in neutrophil cell function is unknown, but an increase in the cortisol ratio: DHEAS in elderly is reported to be associated with decreased oxidative burst function of neutrophil cells (Butcher et al., 2005, Khanfer et al., 2011). By far, the data for the elderly population in Indonesia have not been found.

The flow-cytometry tool can be used to examine the immune cells quantitatively and qualitatively, including the examination of the cell function of the neutrophil oxidative burst function. Oxidative burst describes the ability of neutrophils to produce reactive oxygenespecies (ROS) which are indispensable in the bacterial-killings process after the infectious microbial phagocytosis. This study intends to measure the function of neutrophil cell oxidative burst in healthy older age groups and compare it with younger age groups to reveal decreased neutrophil cell function in elderly people.

\section{METHODS}

This is an analytical observational cross-sectional study. The samples studied were individuals who entered the age group of 18-40 years old, 41-59 years of age and age $\geq 60$ years who met inclusion and exclusion criteria based on consecutive quota sampling.

We excluded patients suffering from acute or chronic infections experiencing psychological or depressed stress, having a history of physical trauma (moderate and severe accidents) in the last 6 months, suffering from degenerative metabolic diseases (including diabetes mellitus, hypertension), obesity (BMI $\geq 25$ ) suffering from malignant blood disorders, smoking habits, using drugs and supplements (statins, immunosuppressants, calcium supplements and antioxidant vitamins), history of moderate or severe physical or exercise activity 1 day before. This study was conducted in he area of Balongsari Health Center, Tandes District, Surabaya.

Anamnesa interview, physical examination and simple laboratory examination including complete blood, random blood sugar, liver function (SGOT, SGPT), kidney function (BUN, SK) were performed on the subjects who met the inclusion criteria. Simple laboratory examination used as initial screening, for complete blood examination using SYSMEX KX-21 type device and for clinical chemistry examination using SFRI BSA-3000 type device. If a normal results were obtained, it is followed by examination of the oxidative burst function of the neutrophil cell.

The function of neutrophil cells oxidative burst is the laboratory examination of flow-cytometry to measure the determination of quantitative oxidative burst of neutrophil cells in whole blood. The examination of Oxidative
Burstsel neutrophil function was performed after sampling. Furthermore, a statistical analysis of differences between age groups of 18-40, 41-59 and 60 years old was carried out using multivariate analysis (ANOVA) for normally distributed data or cruciate wallis test for abnormally distributed data. Post hoc test analysis was then performed to find out which variables have significant differences. Data were analyzed using SPSS program. All analysis and differences with $\mathrm{P}$ values of less than 0.05 were considered significant.

\section{RESULTS}

There were 48 subjects who met the inclusion and exclusion criteria, divided into the groups of young age, middle age and old age with 16 subjects respectively. The subjects consisted of 24 male $(50 \%)$ and 24 female $(50 \%)$. Each of the three age group consisted of 8 males and 8 females.

The subjects' mean of age was $48.44 \pm 16.46$ years old, with the youngest age being 20 years old and the oldest 74 . In the young age group the mean was $28.75 \pm 6.66$ years old, with the youngest age of 20 years old and the oldest 37 . In the middle age group age mean was $50.19 \pm 5.46$ years old, with the youngest age of 41 years old and the oldest 58 years old. The mean of old age group was 66.38 \pm 3.83 years old, with the youngest age of 61 years and the oldest 74 years old.

General characteristics of the study sample for hemoglobin, erythrocyte, leukocyte, thrombocyte, $\%$ neutrophil, lymphocyte, body mass index, random blood sugar, liver function (SGOT, SGPT), kidney function (BUN, SK), used for preliminary screening of patients all showed results within normal limits as seen in table 1.

\section{Function of Oxidative Burst Netrophil Cells among Young Age, Middle Age and Old Age Groups}

Examination of oxidative burst function of neutrophil cells using flow-cytometry tool FACS calibur (Flourescence Activated Cell Sorter), and reagents used are Phagoburst ${ }^{\mathrm{TM}}$ with E coli bacteria as the stimulant. Neutrophil cells that are stimulated by $\mathrm{E}$ coliakan bacteria produce oxidative burst which includes anion superoxide (O2-), hydrogen peroxide $(\mathrm{H} 2 \mathrm{O} 2)$, hydroxyl radicals $(\check{\mathrm{z} O H})$ and hypochlorous acid ( $\mathrm{HOCl})$. The compounds are detected by labelfluorescentdihydrorhodamin (DHR) recognized by flowcytometer. The result shown is the percentage graph of the oxidized neutrophil cell shown in Figure 1.

The result of checking the function of neurotrophil cell nitroxiloxidative burst showed that the mean was $96.83 \pm$ $2.97 \%$ with the lowest level of $88.34 \%$ and the highest of $99.81 \%$. In the young age group the average function of oxidative burst of neutrophil cell was $98.57 \pm 0.98 \%$, with the lowest level being $96.43 \%$ and the highest was $99.81 \%$. In the middle age group the average function of neutrophil oxidative burst cells was $97.71 \pm 1.64 \%$, with the lowest level of $93.27 \%$ and the highest of $99.44 \%$. In the elderly group the average function of neutrophil oxidative burst cells was $94.20 \pm 3.56 \%$, with the lowest level of $88.34 \%$ and the highest was $99.39 \%$. The average function of neutrophil oxidative burst cells between different age groups as seen in figure 2 .

The level mean of netrophil oxidative burst cells function in the male group was $96.75 \pm 3.11 \%$ and in the female group was $96.9 \pm 2.89 \%$. The function of neutral oxidative burst cells in young age group was $98.68 \pm 0.7 \%$ for male and for female was $98.46 \pm 1.23 \%$. In middle age 
group for male was $98.01 \pm 0.83 \%$ and for female was 97.4 $\pm 2.2 \%$. For old age group for male was $93.56 \pm 3.6 \%$ and for female was $94.85 \pm 3.63 \%$.

\section{Differences of Neutrophil Cell Oxidative Burst Function among Young Age, Old Age And Old Age Groups}

In data normality test using Shapiro-Wilk, the $\mathrm{p}$ value obtained was $>0.05$ which indicates normal data distribution. Thus, the statistical test was conducted using a parametric test (one way ANOVA).

Comparison of neutrophils oxidative burst function among various age groups after analyzed using one way ANOVA comparison analysis showed a significant difference with $\mathrm{p}=0.000$ (significant when $\mathrm{p}<0.05$ ), suggesting that there are at least 2 age groups with significant differences. A homogeneity test of variance showed $p=0.000$ (significant when $p<0.05$ ), indicating that there were at least 2 age groups having different variants. Rank Spearman test results showed significant results with $\mathrm{r}=-0.590(\mathrm{p}=0.000)$, which means that there is a negative trend with moderate strength $(0.4-<0.6)$ indicating that with increasing age there is a decrease in oxidative burst function of neutrophil cells.

Scater-plot among the age groups with neutrophil cell oxidative burst function showed a downward trend (negative), where increased age is followed by decreased oxidative burst function of neutrophil cells as seen in figure 3.

Table 1. Subjects' General Characteristics

\begin{tabular}{|c|c|c|c|c|}
\hline Characteristics & $(n=48)$ & $\begin{array}{c}\text { Young } \\
\text { (18-40years) }\end{array}$ & $\begin{array}{c}\text { Adult } \\
(41-59 \text { years })\end{array}$ & $\begin{array}{c}\text { Elderly } \\
\text { ( } \geq 60 \text { years) }\end{array}$ \\
\hline \multicolumn{5}{|l|}{ Sex } \\
\hline Male(n) & 24 & 8 & 8 & 8 \\
\hline Female(n) & 24 & 8 & 8 & 8 \\
\hline Age(year) & $48.44 \pm 16.46$ & $28.75 \pm 6.66$ & $50.19 \pm 5.46$ & $66.38 \pm 3.83$ \\
\hline $\mathrm{Hb}(\mathrm{gr} / \mathrm{dL})$ & $13.26 \pm 1.11$ & $13.58 \pm 1.29$ & $13.31 \pm 1.03$ & $12.92 \pm 0.81$ \\
\hline RBC (x10 $\mathrm{gr} / \mathrm{dL})$ & $4.65 \pm 0.43$ & $4.74 \pm 0.42$ & $4.74 \pm 0.41$ & $4.47 \pm 0.37$ \\
\hline $\mathrm{WBC}\left(\mathrm{x} 10^{3} \mathrm{gr} / \mathrm{dL}\right)$ & $6402 \pm 1202$ & $6656 \pm 1193$ & $6062 \pm 1174$ & $6487 \pm 1122$ \\
\hline Plt(sel/LP) & $273354 \pm 52166$ & $276500 \pm 58922$ & $269313 \pm 46874$ & $274250 \pm 47934$ \\
\hline Neutrophil(\%) & $57.80 \pm 7.25$ & $59.29 \pm 6.18$ & $59.53 \pm 5.85$ & $54.58 \pm 8.12$ \\
\hline lymphocytes (\%) & $32.67 \pm 7.25$ & $31.19 \pm 6.30$ & $31.7 \pm 5.85$ & $35.13 \pm 8.43$ \\
\hline $\mathrm{BMI}\left(\mathrm{Kg} / \mathrm{m}^{2}\right)$ & $22.95 \pm 1.35$ & $23.03 \pm 1.34$ & $22.86 \pm 1.56$ & $22.95 \pm 1.04$ \\
\hline Blood glucose (gr/dL) & $87(80-109)$ & $87(80-102)$ & $87(81-98)$ & $88(81-109)$ \\
\hline $\operatorname{SGOT}(\mu / L)$ & $19.35 \pm 6.69$ & $21.75 \pm 7.05$ & $17.88 \pm 5.90$ & $18.43 \pm 6.16$ \\
\hline $\mathrm{SGPT}(\mu / \mathrm{L})$ & $21.69 \pm 6.46$ & $22.88 \pm 4.75$ & $23.43 \pm 5.77$ & $18.75 \pm 7.32$ \\
\hline BUN(mg/dL) & $10.21 \pm 2.31$ & $9.75 \pm 1.95$ & $9.75 \pm 1.79$ & $11.13 \pm 2.74$ \\
\hline $\mathrm{SK}(\mathrm{mg} / \mathrm{dL})$ & $1.1(0.6-1.4)$ & $1.1(0.8-1.3)$ & $1.1(0.8-1.3)$ & $1.2(0.6-1.4)$ \\
\hline
\end{tabular}

Note: $\mathrm{HB}=$ Hemoglobin, $\mathrm{RBC}=$ Red blood cells, $\mathrm{WBC}=$ white blood cells, $\mathrm{Plt}=$ platelets, $\mathrm{BMI}=$ Body Mass Index (in mean $\pm \mathrm{SD}$, and median (nilai minimum-maksimum), normal score (blood glucose $=70-110 \mathrm{mg} / \mathrm{dL}, \mathrm{SGOT}=<37,0 \mu / \mathrm{L}, \mathrm{SGPT}=$ $<40,0 \mu / \mathrm{L}, \mathrm{BUN}=6,0-20 \mathrm{mg} / \mathrm{dL}, \mathrm{SK}=0,5-1,5 \mathrm{mg} / \mathrm{dL})$. 

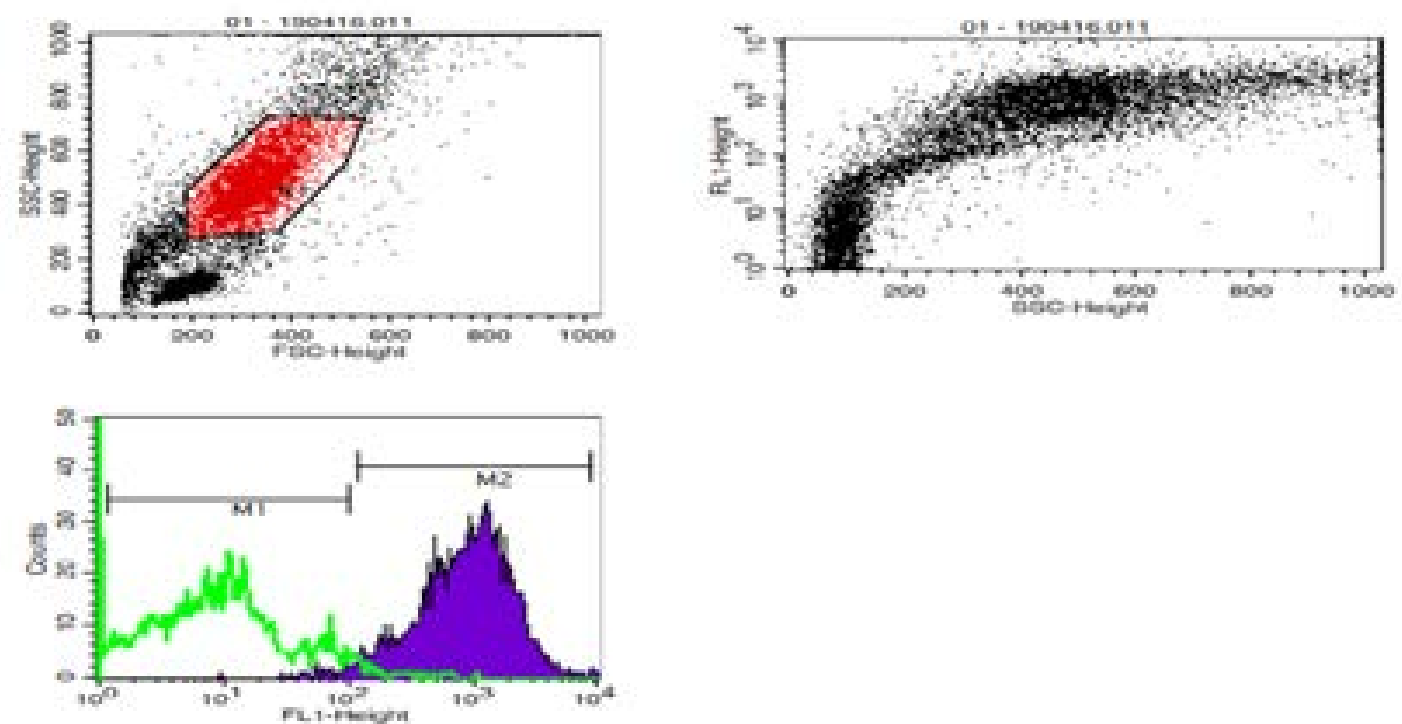

Figure 1. Examination on Neutrophil Cell Oxidative Burst Function Using flow-cytometry Figure (a) and (b) shows distribution of leucocyte cells, the image (a) shows the gate of neutrophil cell, the image (c) shows the percentage graph of the oxidized neutrophil cell .

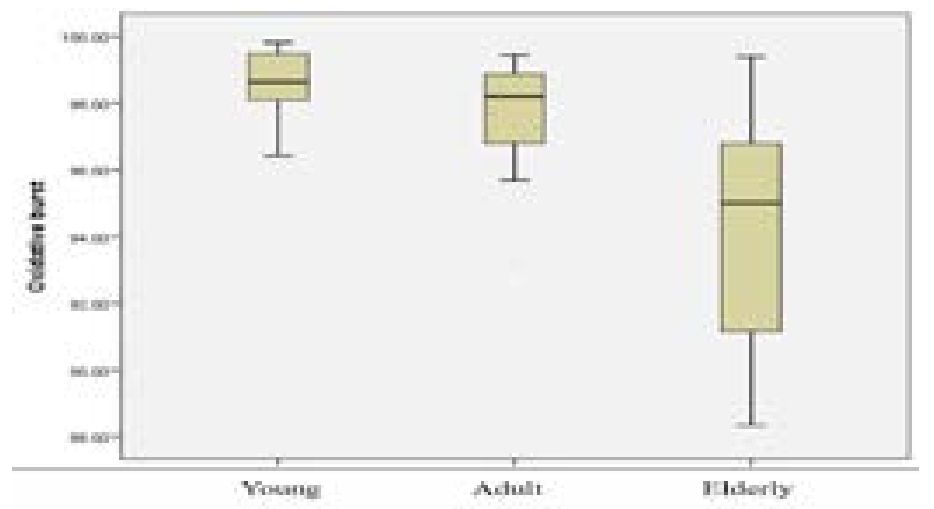

Figure 2. Neutrophil Cell Oxidative Burst Function among Various Age Groups

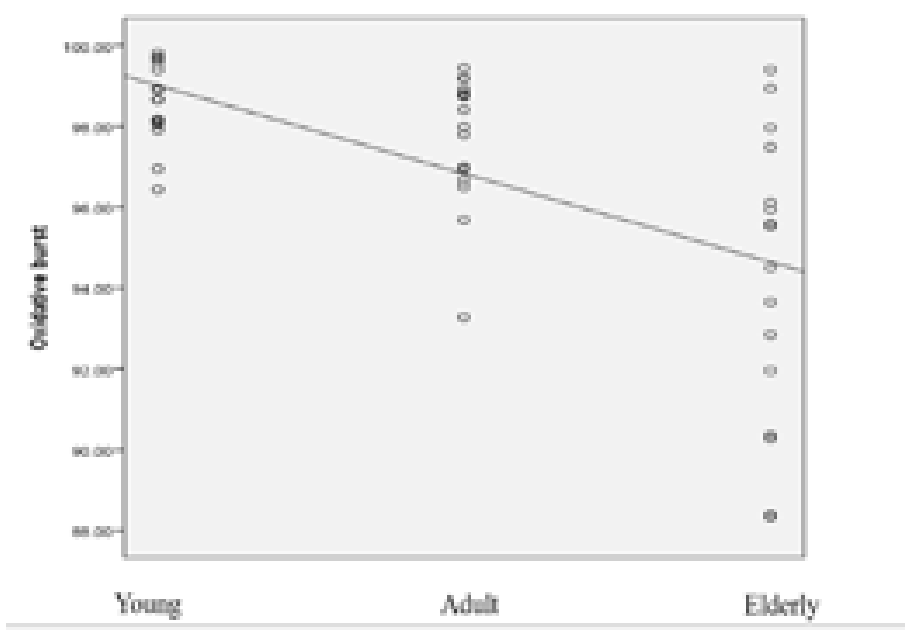

Figure 3. Scatter-plot of Neutrophil Cell Oxidative Burst Function Cell among Age Groups 


\section{DISCUSSION}

The age range and the number of female and male subjects in this study were similar to those of a research conducted with a sample of 34 healthy subjects divided into 3 age groups. Group 1 (aged 21-36 years), consisting of 6 males and 5 females, have age mean of $27 \pm 5$ years old. Group 2 (aged 38-56 years), consisting of 6 males and 6 females have the age mean of $45 \pm 7$. Group 3 (aged 62-83 years), consisting of 6 males and 5 males have the age mean of 71 \pm 7 years old (Wenisch et al., 2000).

Simple laboratory results showed complete blood results, blood sugar, liver function and kidney function within normal limits. Body Mass Index (BMI) results also did not show any obesity $(\mathrm{BMI}<25)$. In taking the study subjects of healthy individuals with restrictions of all samples independent of factors affecting the function of neutrophil oxidative burst cells are, among others, free of autoimmune disease, the presence of infectious diseases, the absence of cancer, and not taking anti-inflammatory drugs or steroids (Tortorella et al., 2007, Wenisch et al., 2000).

The results of the examination on neutrophil oxidative burst cells function in this study showed decreasing trend in line with age. The yield of neutrophil cell oxidative burst function among the younger age group was higher than in middle age group, and in the middle age group the content of the function of neutrophil oxidative burst cells was higher than the elderly group. The previous studies in the elderly group showed that the ability of neutrophil cells to produce Reactive Oxigene Species (ROS) decreased significantly. The decrease was due to many factors, caused by signal delivery disturbances in neutrophil cells due to old age, changes in cyclic adenosine monophosphate/protein kinase A (cAMP/PKA) and P38 mitogen-activated protein kinase (P38 MAPK) signaling pathways resulting in changes in production ROS in the elderly (Chaves et al., 2007). Changes in signal delivery in the granulocyte-macrophage colony stimulating factor (GM-CSF), Toll-Like Receptors (TLRs) and formyl methionyl-leucyl-phenylalanine receptors (fMLPR) cause decreased function of neutrophil cell oxidative burst in older age group (Braga et al., 1998, Larbi et al., 2005).

The results of this study showed no difference in the function of neutrophil cell oxidative burst between male and female subjects in each age group. There is no explanations on the difference. Some factors that can decrease the function of neutrophil oxidative burst cells are due to age factor, but it can also be caused by blood glucose levels, history of trauma, severe psychological stress (bereavement, depression), statin use, obesity, hypertension, and exercise. Meanwhile, the production of ROS by mitochondria is known to be influenced also by several factors including calcium supplementation and intracellular $\mathrm{Ca} 2+$ mobilization (Brookes et al., 2004, Konopka et al., 2015).

The level of neutrophil oxidative burst function also varied among age groups. The normal function of neutrophil oxidative burst cells in healthy young adults with E coli stimulation should be between $96-100 \%$ oxidizing cells, but many subjects showed the results below the normal range although the subjects are from young and middle age groups. This is probably due to the fact that the function of neutrophil cell oxidative burst is influenced by multifactorial, intrinsic (extrinsic) and extrinsic (environmental) factors that are difficult to control such as the type of dietary content, the type of exercise and the type of physical activity daily.
Exercise was restricted on one day before the blood test. The detailed information about types of exercise, daily activity and food intake were not explained on this research, although another study said that calcium, vitamin and antioxidant diet can affect the oxidative burst function of neutrophil cells.

In some studies it has been reported that the number of neutrophil cells in the circulation increases after exercise activity as a result of neutrophil cell demargination of endothelial tissue (mediated by catecholamines) and from bone marrow (mediated by cortisol), or as an inflammatory and phagocytic response to tissue damage induced by sports activities (Pyne, 1994). The data show that neutrophil cells are mobilized into circulation within the first few hours after moderate exercise activity. This mobilized netrophil cell population is directly activated in response to exercise activity, but its oxidative activity varies depending on the type and intensity of exercise performed (Pyne, 1994, Syu et al., 2012).

Some types of intake of food consumed daily including types of diets and vitamins contained in daily food such as foods containing vitamin $\mathrm{C}$ and vitamin $\mathrm{E}$ can reduce the production of PMN superoxide on invitro research (Fuller et al., 2000). Vitamin C is a water-soluble antioxidant stored at high concentrations having an effect on neutrophil cells in regulating ROS production. There have been several in vitro studies showing that vitamin $\mathrm{C}$ has a strong regulatory effect on neophyte in ROS production(Peake $\mathrm{J}$ and Suzuki K, 2008).

Comparison of the function of oxidative burst neutrophil cells between various age groups after analysis using a oneway ANOVA comparison analysis showed a significant difference with $p=0.000$ (significant if $p<0.05$ ). Then a post-hoc-Tamhane analysis was performed to find out which groups are different, the results showed that there were no significant differences between the young and middle age groups, contrarily there are significant differences between the young and old age groups as well as middle age and old age groups. The significant difference that was found in the old age group means that significant decrease in the function of oxidative burst neutrophil cells has occurred.

Analysis result of this study on neutrophil cell oxidative burst level among the age groups showed decreasing trend (negative) in which the age increase is followed by decreased function of neutrophil oxidative burst cells. Spearman Rank test showed significant result with $\mathrm{r}=$ $-0.590(p=0.000)$ with medium strength (0.4-0.6).

\section{CONCLUSION}

There was a significant difference between the young and the elderly, and there was a significant difference between the middle age group and the elderly group, but there was no significant difference between the young and middle age group. There is a negative trend between increasing age and decreased function of neutrophil oxidative burst cells. With increasing age there is a decrease in oxidative burst function of neutrophil cells. Decreased function of neutrophil cell oxidative burst especially started in the age group of $\geq 60$ years.

\section{CONFLICT OF INTEREST}

The author declare there is no conflict of interest of this study. 


\section{REFERENCES}

Balcombe, N. R. \& Sinclair, A. 2001. Ageing: Definitions, Mechanisms and the Magnitude of the Problem. Best Pract Res Clin Gastroenterol, 15, 835-49.

Bekesi, G., Kakucs, R., Varbiro, S., Racz, K., Sprintz, D., Feher, J. \& Szekacs, B. 2000. In Vitro Effects of Different Steroid Hormones on Superoxide Anion Production of Human Neutrophil Granulocytes. Steroids, 65, 889-94.

Braga, P. C., Sala, M. T., Dal Sasso, M., Mancini, L., Sandrini, M. C. \& Annoni, G. 1998. Influence of Age on Oxidative Bursts (Chemiluminescence) of Polymorphonuclear Neutrophil Leukocytes. Gerontology, 44, 192-7.

Brookes, P. S., Yoon, Y., Robotham, J. L., Anders, M. W. \& Sheu, S. S. 2004. Calcium, Atp, and Ros: A Mitochondrial Love-Hate Triangle. Am J Physiol Cell Physiol, 287, C817-33.

Butcher, S. K., Killampalli, V., Lascelles, D., Wang, K., Alpar, E. K. \& Lord, J. M. 2005. Raised Cortisol:Dheas Ratios in the Elderly After Injury: Potential Impact Upon Neutrophil Function and Immunity. Aging Cell, 4, 319-24.

Chaves, M. M., Costa, D. C., Pereira, C. C., Andrade, T. R., Horta, B. C. \& Nogueira-Machado, J. A. 2007. Role Of Inositol 1,4,5-Triphosphate and P38 Mitogen-Activated Protein Kinase in Reactive Oxygen Species Generation by Granulocytes in a Cyclic Amp-Dependent Manner: an Age-Related Phenomenon. Gerontology, 53, 228-33.

Fuller, C. J., May, M. A. \& Martin, K. J. 2000. The Effect Of Vitamin E And Vitamin C Supplementation On Ldl Oxidizability and Neutrophil Respiratory Burst in Young Smokers. J Am Coll Nutr, 19, 361-9.

Ginaldi, L., Loreto, M. F., Corsi, M. P., Modesti, M. \& De Martinis, M. 2001. Immunosenescence And Infectious Diseases. Microbes Infect, 3, 851-7.

Hadi M 2011. Aspek Fisiologik dan Patologik Akibat Proses Menua, Jakarta, Fkui.

Khanfer, R., Lord, J. M. \& Phillips, A. C. 2011. Neutrophil Function and Cortisol:Dheas Ratio in Bereaved Older Adults. Brain Behav Immun, 25, 1182-6.

Konopka, A. R., Asante, A., Lanza, I. R., Robinson, M. M., Johnson, M. L., Dalla Man, C., Cobelli, C., Amo1s, M. H., Irving, B. A. \& Nair, K. S. 2015. Defects in Mitochondrial Efficiency and $\mathrm{H} 2 \mathrm{o} 2$ Emissions in Obese Women Are Restored To A Lean Phenotype with Aerobic Exercise Training. Diabetes, 64, $2104-$ 15 .
Larbi, A., Douziech, N., Fortin, C., Linteau, A., Dupuis, G. \& Fulop, T., Jr. 2005. The Role Of The Mapk Pathway Alterations in Gm-Csf Modulated Human Neutrophil Apoptosis with Aging. Immun Ageing, 2, 6.

Lord, J. M., Butcher, S., Killampali, V., Lascelles, D. \& Salmon, M. 2001. Neutrophil Ageing and Immunesenescence. Mech Ageing Dev, 122, 1521-35.

Mitchell, J. B., Dugas, J. P., Mcfarlin, B. K. \& Nelson, M. J. 2002. Effect Of Exercise, Heat Stress, and Hydration on Immune Cell Number and Function. Med Sci Sports Exerc, 34, 1941-50.

Orentreich, N., Brind, J. L., Vogelman, J. H., Andres, R. \& Baldwin, H. 1992. Long-Term Longitudinal Measurements of Plasma Dehydroepiandrosterone Sulfate in Normal Men. J Clin Endocrinol Metab, 75, 1002-4.

Peake J and Suzuki K 2008. Neutrophil Activation, Antioxidant Supplements and Exercise-Induced Oxidative Stress. School of Human Sciences and Consolidated Research Institute For Advanced Science and Medical Care, Waseda University, 2, 129-141.Plackett, T. P., Boehmer, E. D., Faunce, D. E. \& Kovacs, E. J. 2004. Aging and Innate Immune Cells. J Leukoc Biol, 76, 291-9.

Pyne, D. B. 1994. Regulation of Neutrophil Function During Exercise. Sports Med, 17, 245-58.

Syu, G. D., Chen, H. I. \& Jen, C. J. 2012. Differential Effects of Acute and Chronic Exercise on Human Neutrophil Functions. Med Sci Sports Exerc, 44, 1021-7.

Tortorella, C., Simone, O., Piazzolla, G., Stella, I. \& Antonaci, S. 2007. Age-Related Impairment of Gm-Csf-Induced Signalling in Neutrophils: Role Of Shp-1 And Socs Proteins. Ageing Res Rev, 6, 81-93.

Weinberger, B., Herndler-Brandstetter, D., Schwanninger, A., Weiskopf, D. \& Grubeck-Loebenstein, B. 2008. Biology of Immune Responses to Vaccines in Elderly Persons. Clin Infect Dis, 46, 1078-84.

Wenisch, C., Patruta, S., Daxbock, F., Krause, R. \& Horl, W. 2000. Effect of Age on Human Neutrophil Function. $J$ Leukoc Biol, 67, 40-5.

Wessels, I., Jansen, J., Rink, L. \& Uciechowski, P. 2010. Immunosenescence of Polymorphonuclear Neutrophils. Scientificworldjournal, 10, 145-60.

Who Regional Office For South East Asia 2004. Health of The Elderly in South East Asia, A Profile, New Delhi, Who-Searo. 